\title{
Microfracture Arthroscopy Efficacy In Treatment Of Articular Cartilage Insult Of Knee
}

\author{
Mohamed Baqir Alshara *, Mohammed Shihab Ahmed **
}

\section{ABSTRACT}

Background: The treatment of articular cartilage defects is one of the most clinical challeng for orthopedic surgeons. Articular cartilage is a highly organized tissue with complex biomechanical properties and substantial durability. However, it has a poor ability for healing, and damage from trauma or degeneration can result in morbidity and functional impairment. debilitating joint pain, dysfunction, and degenerative arthritis Objectives: The purpose of study is to show effectiveness of micro fracture arthroscopy as a method of treatment for such problem .

Type of the study: Cross-sectional study. Methods: Arthroscopic surgery was done to 52 patients who complain of knee pain limping and show clinical or radiological evidence of cartilaginous injury and we used arthroscopic micro fracture technique for those patient who have injury of no more than $4 \mathrm{~cm}^{2}$ then we instruct patient to not put any weight over knee for 2-3 months and followed clinically according to Lyshlom scor and by MRI and some of them by second look arthroscopy to assess the healing. Results: Fifty two patients under go micro fracture arthroscopy . Thirty four patients $(65.4 \%)$ reported good or excellent subjective results , thirteen patients $(25 \%)$ had fair knee function, and only five patients (9.6\%) reported poor result

Conclusions: Micro fracture arthroscopy is a cheap effective method for repairing cartilaginous lesion. key wards: micro fracture ,arthroscopy and articular cartilage

\section{Al-Kindy College Medical Journal 2018: Vol.14 No.1 Page: 24-28}

*Orthopeadic Surgeon Ficms Ortho Md

** Asst. Prof. Orthopedic Surgeon In Al-Kindy College Of Medicine. Ficms Ortho Md

Received $10^{\text {th }}$ January 2017, accepted in final 30 $0^{\text {th }}$ April 2017

Corresponding to: Mohammed Shihab Ahmed
A rticular cartilage is a highly organized tissue with complex biomechanical properties and substantial durability. However, it has a poor ability for healing, and damage from trauma or degeneration can result in morbidity and functional impairment. debilitating joint pain ,dysfunction, and degenerative arthritis (1). Articular cartilage defects of the knee are habitually watched., The more later prospective study of 993 sequential knee arthroscopies showed confirmation for articular cartilage abnormality over $66 \%{ }^{(2)}$. Articular cartilage defects of the femoral condyles bring additionally been watched alongside dependent part of condyle in half of competitors undergoing for most cruciate ligament reconstruction. Due to their poor spontaneous repair shed potential, these articular cartilage lesions exhibit an clinical orthopedics challenges, especially for youthful furthermore animated people ${ }^{(3)}$. Micro fracture gain utilized strategy used to provoke repair shed about articular cartilage defects of the knee ${ }^{(4)}$. Infiltration of the subchondral bone plate over these defects prompts cluster structuring in the abandon this cluster holds pluripotent, marrow-derived mesenchymal undifferentiated cells which generate a fibrocartilage repair shed for changing sums from claiming type-II collagen content ${ }^{(5)}$.

Microfracture an articular cartilage repair shop surgical methodology that meets desires by making little fractures in the underlying bone. This makes new cartilage which make beginning with a affirmed super-clot ${ }^{(4.5)}$. The individuals surgery is quick typically persisting in expert hands for 3090 minutes ;minimally invasive, need an basically shorter recovery time than a arthroplasty( knee replacemen)t ${ }^{(6)}$ Microfracture just makes minimal holes in the bone the individuals surface layer from asserting bone, known as the individuals subchondral bone, might be steady moreover fizzles with the table with great blood stream eventually 'perusing infiltrating this tricky layer, an microfracture permits the deeper, vascular bone to get to surface layer. This deeper bone had a good blood supply, and then cells get of the surface layer ,furthermore animate cartilage Growth $^{(7.8 .9)}$.

Chronic articular cartilage defects don't heal spontaneously. Reparative fibrocartilage comprises of type-I, type-II, Also type-III collagen on changing sums ${ }^{(10)}$. Those fibro cartilage doesn't look like the encompassing hyaline cartilage. Dissimilar to different cartilage rebuilding techniques, bone marrow incitement doesn't include exchange for chondrocytes under those lese greatness making a contained lesion will be basic with accomplishing an stable base to filling the deformity with an clot and bond of the $\operatorname{clot}^{(8,9)}$.

Assuming that the lese greatness will be not shouldered toward an stable edge for sound cartilage, accomplishing a stable clot might make additional was troublesome. Those calcified cartilage layer in the base of the lese greatness must have a chance to be removed too. Evacuation of this layer will be essential for cluster bond and the ultimacy prosperity of the microfracture method. The readied channels must have a chance to be of addition profundity to guarantee infiltration of the subchondral plate what's more correspondence for those marrow. $(6,10)$. 


\section{Methods}

A fifty two patient complaint of knee pain ,swelling and catching treated by microfracture arthroscopic technique surgery in Al-Shaheed Alsader and al-Muktar private hospitals and they followed for twenty four months by clinical assessment (Lysholm knee scoring scale) ${ }^{(4)}, \mathrm{MRI}$

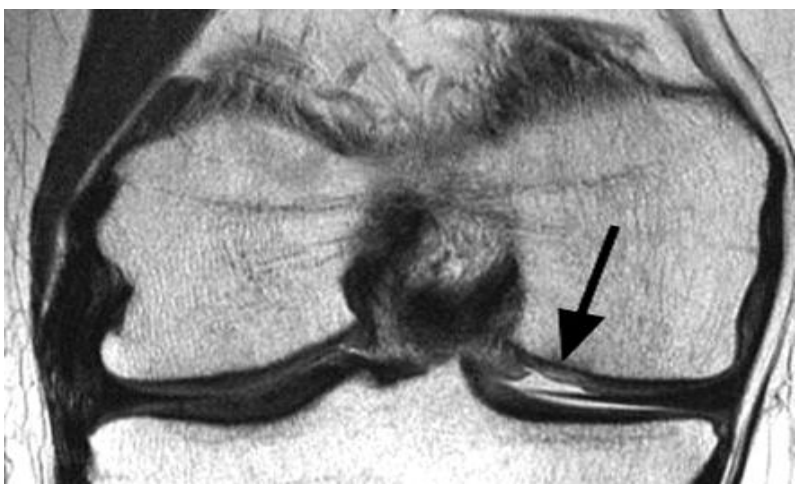

Fig 1: MRI picture of femoral condylar cartilaginous lesion

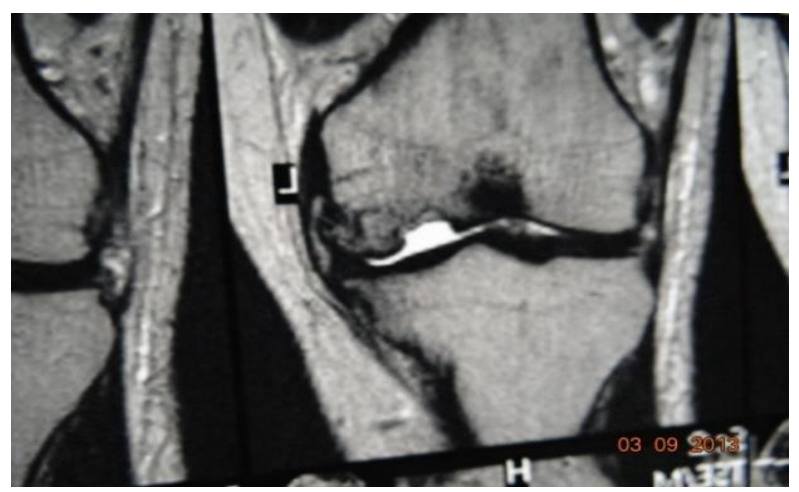

Fig2: MRI picture of femoral osteocondylar cartilaginous lesion

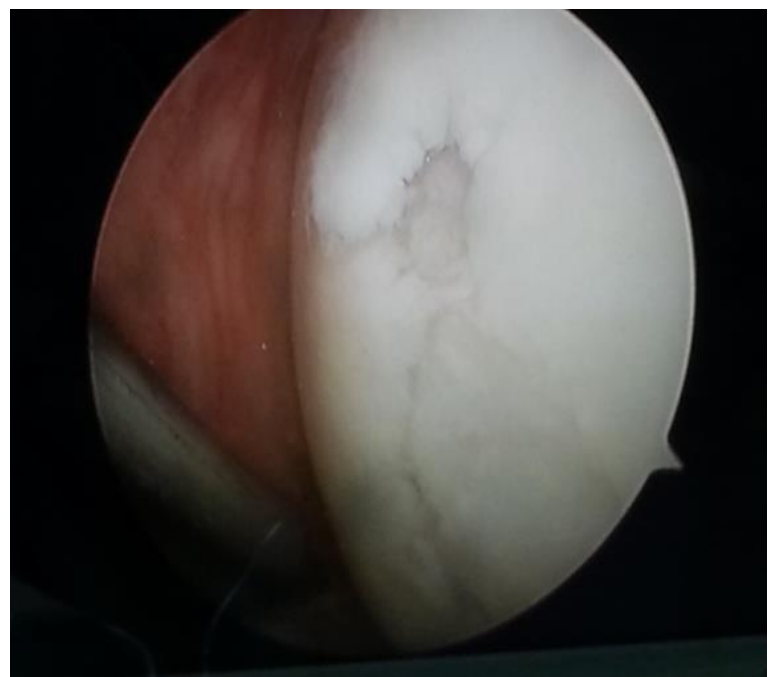

Figure-3-Arthroscopic view of cartilagenuos lesion in young adult 28 years old due to trauma and second look arthroscopy but not all patient because some of them refuse another surgery so about half of patient agreed for second look arthroscopy At two years all patient had been followed except seven patients had removed, were pregnant, or were not available for examination in the outpatient clinic. However, these patient(none of whom had a failure) were contacted by telephone, and they returned their questionnaires.

\section{Inclusion criteria}

1- Optimal patient age should be less than forty-five years ranged from 10 to 45 years.

2. Symptomatic, central chondral lesions of the weight bearing femoral condyles,

3. The ideal knee lesion should be isolated, well contained, and not exceed an area of $4 \mathrm{~cm} 2(2 \times 2$ $\mathrm{cm})$

\section{Exclusion criteria}

1. Generalized degenerative joint changes

2. Uncontained chondral lesions.

3. extreme pivotal malalignment for $>5^{\circ}$ to lesions of the femoral condyle (surgical realignment required).

4. patella maltracking or precariousness for patellofemoral lesions

5. tumor

6. Infection.

7. Body-mass $>30$.

Tegner Lysholm Knee Scoring Scale ${ }^{(4)}$

During the past 4 weeks

\begin{tabular}{|c|c|c|c|}
\hline \multicolumn{2}{|c|}{ Section 1 -Limp } & \multicolumn{2}{|c|}{ Section 2 -Support } \\
\hline 6 & None & 0 & None \\
\hline 0 & $\begin{array}{l}\text { Slight or } \\
\text { periodical }\end{array}$ & 0 & Stick or crutch \\
\hline 0 & $\begin{array}{l}\text { Severe and } \\
\text { constant }\end{array}$ & 0 & $\begin{array}{l}\text { Weight-bearing } \\
\text { impossible }\end{array}$ \\
\hline
\end{tabular}




\begin{tabular}{|c|c|c|c|}
\hline \multicolumn{2}{|c|}{ Section 3 - Pain } & \multicolumn{2}{|c|}{ Section 4 - Instability } \\
\hline $\mathrm{C}$ & None & $\mathrm{C}$ & Never giving way \\
\hline 6 & $\begin{array}{l}\text { Inconstant } \\
\text { and slight } \\
\text { during severe } \\
\text { exertion }\end{array}$ & 0 & $\begin{array}{l}\text { Rarely during } \\
\text { athletics or other } \\
\text { severe exertion }\end{array}$ \\
\hline 10 & $\begin{array}{l}\text { Marked } \\
\text { during severe } \\
\text { exertion }\end{array}$ & $\mathrm{C}$ & $\begin{array}{l}\text { Frequently during } \\
\text { athletics or other } \\
\text { severe exertion } \\
\text { (or incapable of } \\
\text { participation) }\end{array}$ \\
\hline 0 & $\begin{array}{l}\text { Marked on or } \\
\text { after walking } \\
\text { more than } 2 \\
\text { km }\end{array}$ & 0 & $\begin{array}{l}\text { Occasionally in } \\
\text { daily activities }\end{array}$ \\
\hline 10 & $\begin{array}{l}\text { Marked on or } \\
\text { after walking } \\
\text { less than } 2 \\
\text { km }\end{array}$ & 0 & $\begin{array}{l}\text { Often in daily } \\
\text { activities }\end{array}$ \\
\hline 0 & Constant & 0 & Every step \\
\hline
\end{tabular}

\begin{tabular}{|c|c|c|c|}
\hline \multicolumn{2}{|c|}{ Section 5 -Locking } & \multicolumn{2}{|c|}{$\begin{array}{l}\text { Section } 6 \text { - } \\
\text { Swelling }\end{array}$} \\
\hline 0 & $\begin{array}{l}\text { No locking and no } \\
\text { catching sensations }\end{array}$ & $\mathrm{C}$ & None \\
\hline 0 & $\begin{array}{l}\text { Catching sensation but } \\
\text { no locking }\end{array}$ & $\mathrm{r}$ & $\begin{array}{l}\text { On } \\
\text { severe } \\
\text { exertion }\end{array}$ \\
\hline 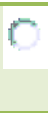 & LockingOccasionally & r & $\begin{array}{l}\text { On } \\
\text { ordinary } \\
\text { exertion }\end{array}$ \\
\hline 0 & Frequently & 10 & Constant \\
\hline 0 & $\begin{array}{l}\text { Locked joint on } \\
\text { examination }\end{array}$ & & \\
\hline
\end{tabular}

\begin{tabular}{|c|c|c|c|}
\hline \multicolumn{2}{|c|}{$\begin{array}{l}\text { Section } 7 \text { - Stair- } \\
\text { climbing }\end{array}$} & \multicolumn{2}{|c|}{ Section 8 - Squatting } \\
\hline $\mathrm{C}$ & No problems & (c) & No problems \\
\hline 6 & $\begin{array}{l}\text { Slightly } \\
\text { impaired }\end{array}$ & 0 & $\begin{array}{l}\text { Slightly } \\
\text { impaired }\end{array}$ \\
\hline 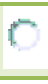 & $\begin{array}{l}\text { One step at a } \\
\text { time }\end{array}$ & 0 & Not beyond $90^{\circ}$ \\
\hline 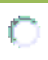 & Impossible & 10 & Impossible \\
\hline
\end{tabular}

\begin{tabular}{|l|r|r|r|r|r|r|r|}
\hline \multicolumn{1}{|c|}{ Grading the Tegner Lysholm Knee Scoring Scale } \\
\hline$<65$ & Poor & $\begin{array}{r}65- \\
83\end{array}$ & Fair & $\begin{array}{r}84- \\
90\end{array}$ & Good & $>90$ & Excellent \\
\hline
\end{tabular}

Tab. 1 : Tegner Lysholm scoring Scale

\section{Surgical procedure}

All of the patients treated by microfracture arthroscopic technique under general anesthesia and tourniquet applied .The marrow-stimulation technique required bed preparation by using a curette or a full- radius shaver blade to remove any remaining fragment of articular cartilage. Loose fragment should also be removed at the lesion's margin and vertical wall of well attached healthy cartilage should be created. The subchondral plate should not be penetrated but the calcified cartilage layer above it removed with curette .Multiple penetrating holes are placed 3 to $4 \mathrm{~mm}$ apart throughout the bed of lesion fig $4,5,6$. After surgery we put back slab above knee for next two weeks and stitches removal after ten days, we follow the patients clinically by using Lysholm knee scoring scale, MRI and second look arthroscopic

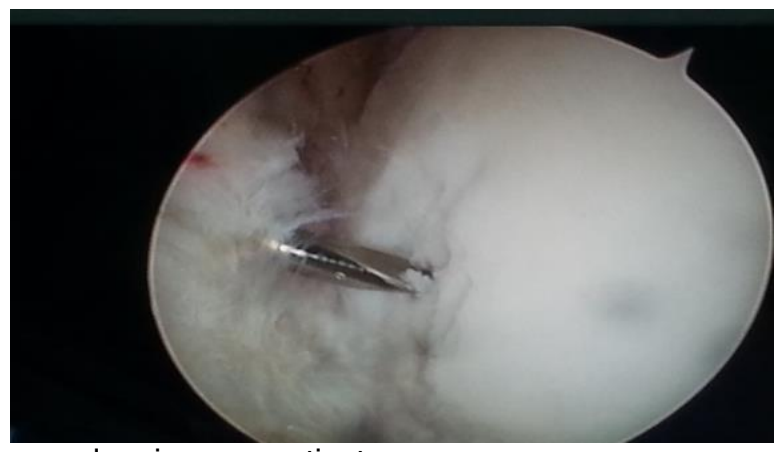

procedure in some patients

Fig 4After debridment of edges of lesion

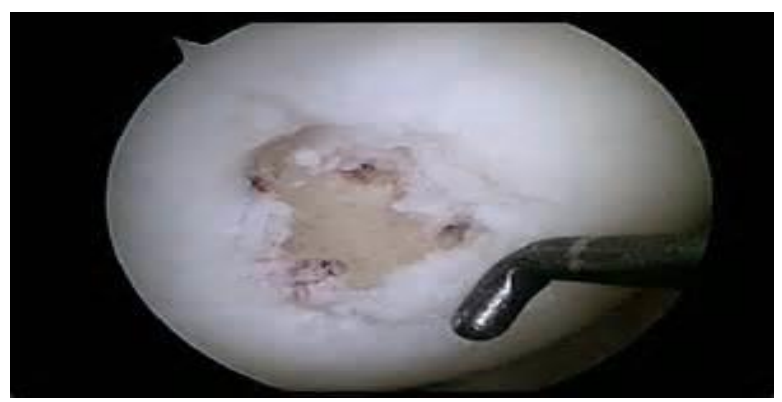

Fig 5:The lesion then penetration of subcondylar bone
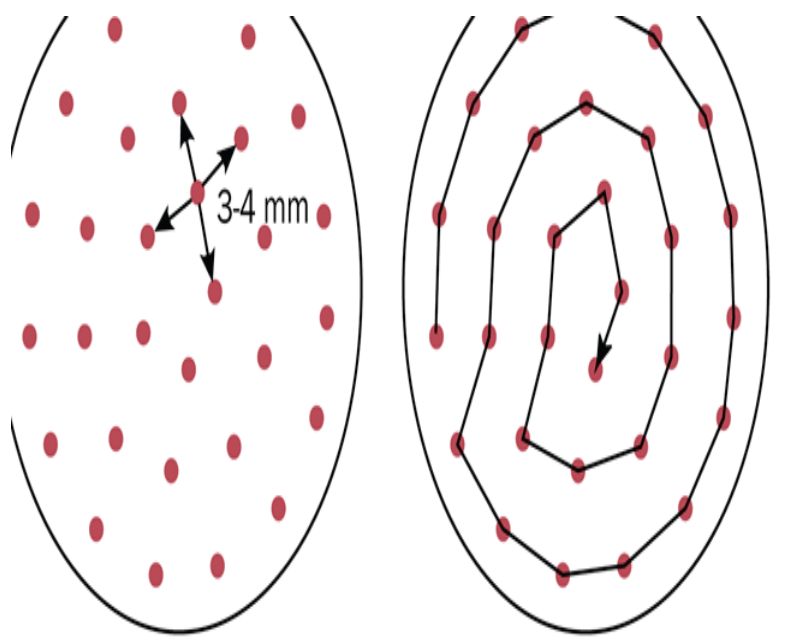

Fig. 6: Illustrating the systematic spiral pattern of microfracture penetrations of the subchondral bone plate throughout the cartilage lesion, allowing for a homogeneous distribution of the microfractures while 
maintaining sufficient subchondral bone bridges between individual penetrations

Results: Fifty-two symptomatic patients with a fullthickness articular cartilage defects of the femur in a stable knee were treated with the microfracture technique. Prospective evaluation of patient outcome was performed for a minimum follow-up of twenty four months with a combination of subjective clinical examination and assessment, magnetic resonance imaging and second look arthroscopic examination. There were 29 women(55.8\%) and 23 men(44.2\%) with average of 25 -55years old and 29 (55.8\%) of them were with cartilaginous lesion due to trauma ,11(21.2\%) of them due to degenerative, four of patients $(7.7 \%)$ due to foreign body inside the knee and eight patients(15.4\%) due to patellofemoral overload syndrome tab. 1 . The traumatic in 33 patients (63.5\%) and non traumatic in 19 patients $(36.5 \%)$.All of our patient not gone through surgery before our procedure but having different kinds of medical treatment and intra articular injection without benefit. The preoperative duration of symptoms range( 12 to 48 months). The mean body-mass index was $26 \pm$ $3 \mathrm{~kg} / \mathrm{m} 2$ (range 20 to $29 \mathrm{~kg} / \mathrm{m} 2$ ). The lesion size averaged $380 \mathrm{~mm} 2$ (range, 200 to $290 \mathrm{~mm} 2$ ). The lesions were located on the medial femoral condyle in 27 of patients $(51.9 \%)$, thirteen patients in lateral femoral condyle (25\%), and 12 patients in trochlea (23.1\%). tab 2Forty two patients $(80.8 \%)$ the defects were chondral lesions, while the remaining ten patients ( 19.2 $\%$ ) were osteochondral lesions without cavitation.

Tab 1 : The causes of aricular cartilage insult

\begin{tabular}{|l|c|c|}
\hline Causes & $\begin{array}{c}\text { No. of } \\
\text { patient }\end{array}$ & $\%$ \\
\hline Trauma & 29 & 55.8 \\
\hline Degenerative disease & 11 & 21.2 \\
\hline Foreign body & 3 & 5.8 \\
\hline Patello-femoral overlap & 8 & 15.4 \\
\hline
\end{tabular}

Tab 2 : The site of the lesion

\begin{tabular}{|l|c|c|}
\hline Site & No. of patients & $\%$ \\
\hline Medial femoral condyle & 27 & 51.9 \\
\hline Lateral femoral condyle & 13 & 25 \\
\hline Trochlea & 12 & 23.1 \\
\hline
\end{tabular}

Tab 3 : Clinical outcome according to Lyshlom score

\begin{tabular}{|l|c|c|}
\hline Outcome & No. of the patients & $\%$ \\
\hline Good to excellent & 34 & 65.4 \\
\hline Fair & 13 & 25 \\
\hline Poor & 5 & 9.8 \\
\hline
\end{tabular}

At the time of the two-years follow-up, there were five patients failure $(8 \%)$ they retain some pain and intermittent swelling and they asked to do second look arthroscopic surgery they refused except two of them . one of those patient had a good reasonable healing but developed another lesion in other site and other one need more time for healing for second look arthroscopy after three months from original first surgery. Thirteen patients $(25 \%)$ had fair knee function, and only five patients $(8 \%)$ reported poor result.tab 3 . Daily activities after micro fracture arthroscopy had increased according to lyshlom scoring system . Magnetic resonance imaging demonstrated a hyperintense signal in the repair cartilage in thirty-seven $(71.1 \%)$ of patients and mild subchondral edema in fifteen patients $(28.1 \%)$. Repair cartilage fill was graded as good in the majority of patients, but most treated lesions demonstrated depressed repair cartilage morphology relative to the adjacent hyaline cartilage .fig $7 \& 8$.
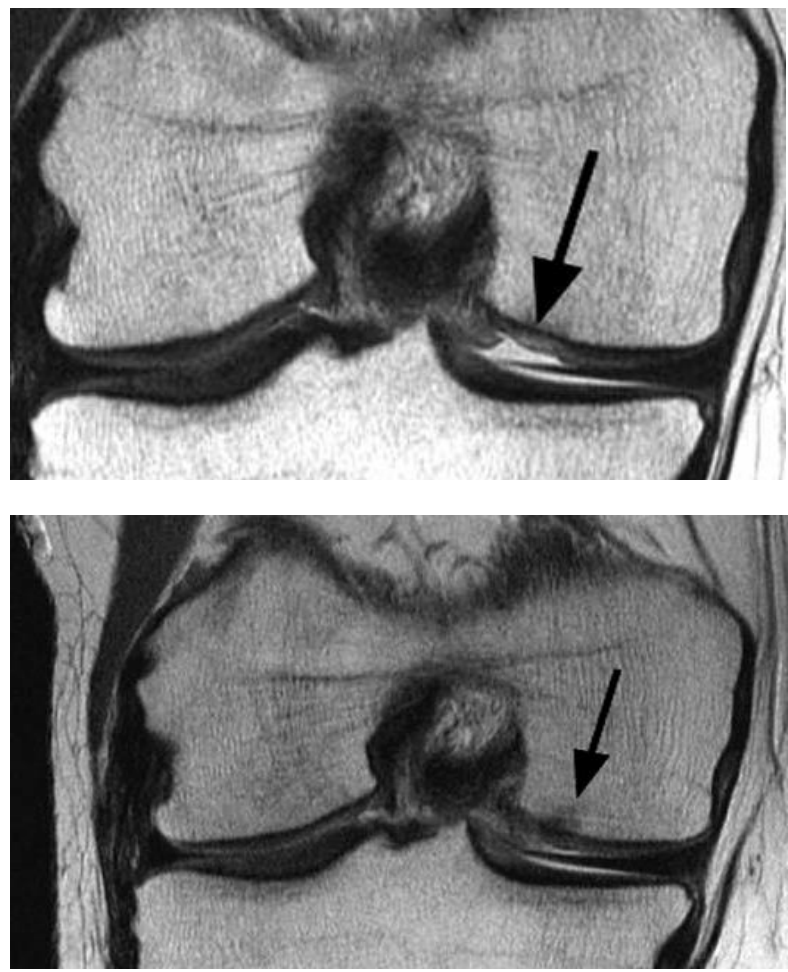

Fig 7\&8 thirty-three-year-old woman who had a fullthickness articular cartilage defect of the medial femoral condyle before and after microfracture arthroscopy

Discussion : This study demonstrated about how the microfracture chondroplasty can resulted in increased functional scores in patients treated for symptomatic cartilage lesion at follow-up of two years

In the long-term study by Steadman et al ${ }^{(7)}$, which involved a cohort of seventy-one knees treated with microfracture chondroplasty, the mean Lysholm score improved from 59 before surgery during of follow-up 12 monthsto 82 score. The greatest improvement occurred in the first year after surgery, but improvement continued for two to three years postoperatively. In contrast,other studies of microfracture have shown deterioration of results over time ${ }^{(3,4,5)}$.Also Steadman et al $^{(7)}$ reported that their patients had substantial increases in the ability to perform the activities of daily living, strenuous work, and sports after microfracture. The over all result in our study is parallel to other studies both clinical (lysholm score) (7,11,12,13) and second look arthroscopic surgery as if we compare to other studies ${ }^{(7,13)}$ there is a good functional result about $85 \%-90 \%$ after 8 weeks non 
weight bearing and follow up of 2 years when patient experienced maximum improvement that's probably because of increasing cartilage lay down over time. The preoperative duration of symptoms was found to be an important factor for cartilage repair with microfracture chondoplasty in our study, as significantly patients with preoperative time of more than six months showed improved activities of daily living scores. Similarly, prolonged preoperative intervals mostly more than six months also have been associated with an inferior grade of repair cartilage at second-look arthroscopy after microfracture. Previous studies shown relation between age and result of microfracture as they shown there is a good result in patient under age of thirty ${ }^{(6,10)}$.In our study we observed such finding that the clinical outcome and the healing that was observed by second look arthroscopy for patient who did so probably because of age depending healing capacity of cartilage which related to difference in metabolic rate however we cannot confirm because we have no solid statistical studies about how much age related to cartilage healing. Body-mass index was inversely correlated with the activities of daily living score. Patients with a body-mass index of $>30 \mathrm{~kg} / \mathrm{m} 2$ demonstrated the lowest outcome scores and the worst subjective rating. Osseous overgrowth following microfracture has not been well described and was observed in $5 \%$ of the patients who did magnetic resonance imaging post operative in our study. This phenomenon is thought to result from metaplasia of the deep layer of the repair cartilage after microfracture stimulation and has been demonstrated in up to $49 \%$ of patients after microfracturein the knee ${ }^{(14)}$. The factors responsible for the development of osseous overgrowth still not been figured out, but excess breaching of the subchondral bone plate during drilling or shaving of the calcified cartilage layer may promote vascularization of the base of the repair tissue and provide a stimulus for endochondral ossification ${ }^{(15)}$.

The problem facing this study was absence of control study and weak compliance of patient for follow up and for second look arthroscopy in spite of that we were able to demonstrate significant changes in knee function and were able to identify several factors that influence functional outcome after microfracture by using instruments that have been previously validated for the knee. We routinely asked for second look arthroscopy because we have no cartilage sensitive magnetic resonance imaging which provides reliable information about repair cartilage filling and integration with additional evaluationof the underlying subchondral bone plate with respect to integrity and overgrowth .

\section{References}

1. Hunter W (1743) "On the structure and diseases of articulating cartilages." Trans R Soc Lond 42B:51421

2. Curl WW, Krome J, Gordon ES, Rushing J, Smith BP, Poehling GG. Cartilage injuries:a review of 31,516 knee arthroscopies. Arthroscopy. 1997;13:456-60.

3. Gobbi A, Nunag P, Malinowski K. Treatment of full thickness chondral lesions of the knee with microfracture in a group of athletes. Knee Surg Sports Traumatol Arthrosc. 2005;13:213-21.
4. Mithoefer K, Williams RJ 3rd, Warren RF, Potter HG, Spock CR, Jones EC,Wickiewicz TL, Marx RG. The microfracture technique for the treatment of articular cartilage lesions in the knee. A prospective cohort study. J Bone Joint Surg Am. 2005;87:1911-20

5. Gudas R, Stankevicius E, Monastyreckiene E, Pranys D, Kalesinskas RJ. Osteochondral autologous transplantation versus microfracture for the treatment of articular cartilage defects in the knee joint in athletes. Knee Surg Sports Traumatol Arthrosc. 2006; 14:834-42

6. Knutsen G, Engebretsen L, Ludvigsen TC, Drogset JO, Grontvedt T, Solheim E,Strand T, Roberts S, Isaksen V, Johansen O. Autologous chondrocyte implantation compared with microfracture in the knee. A randomized trial. J Bone Joint Surg Am. 2004;86:455-64.

7. Steadman JR, Rodkey WG, Singleton SB, Briggs KK. Microfracture technique for full-thickness chondral defects. Technique and clinical results. Oper Tech Orthop. 1997;7:300-4.

8. Gobbi A, Nunag P, Malinowski K. Treatment of full thickness chondral lesions of the knee with microfracture in a group of athletes. Knee Surg Sports Traumatol Arthrosc. 2005;13:213-21.

9. Blevins FT, Steadman JR, Rodrigo JJ, Silliman J. Treatment of articular cartilage defects in athletes: an analysis of functional outcome and lesion appearance.Orthopedics. 1998;21:761-8.

10. Steadman JR, Briggs KK, Rodrigo JJ, Kocher MS, Gill TJ, Rodkey WG.Outcomes of microfracture for traumatic chondral defects of the knee: average 11year follow-up. Arthroscopy. 2003;19:477-84.

11. Frisbie DD, Oxford JT, Southwood L, Trotter GW, Rodkey WG, Steadman JR, Goodnight JL, Mcllwraith CW. Early events in cartilage repair after subchondral bone microfracture. Clin Orthop Relat Res. 2003;407:215-27.

12. Blevins FT, Steadman JR, Rodrigo JJ, Silliman J. Treatment of articular cartilage defects in athletes: an analysis of functional outcome and lesion appearance. Orthopedics. 1998;21:761-8.

13. Mithoefer K, Williams RJ 3rd, Warren RF, Potter HG, Spock CR, Jones EC, Wickiewicz TL, Marx RG. The microfracture technique for the treatment of articular cartilage lesions in the knee. A prospective cohort study. J Bone Joint Surg Am. 2005;87:1911-20

14. Brown WE, Potter HG, Marx RG, Wickiewicz TL, Warren RF. Magnetic resonance imaging appearance of cartilage repair in the knee. Clin Orthop Relat Res.2004;422:214-23

15. Piasecki DP, Spindler KP, Warren TA, Andrish JT, Parker RD. Intraarticular injuries associated with anterior cruciate ligament tear: findings at ligament reconstruction in high school and recreational athletes. An analysis of sex-based differences. Am J Sports Med. 2003;31:601-5 